\title{
PERSPECTIVA MITICA DE LA REALIDAD HISTORICA EN DOS CUENTOS DE ARTURO USLAR PIETRI
}

\author{
POR \\ TERESITA J. PARRA \\ University of North Carolina at Wilmington
}

Una de las bases fundamentales para el entendimiento de la obra del escritor venezolano Arturo Uslar Pietri es su concepción de la realidad. Especialmente en sus cuentos, el autor descarta la superficialidad aparente de la realidad para poner mayor énfasis en el misterio que late en su interior, palpa en ella lo maravilloso, "una adivinación poética o una negación poética de la realidad. Lo que, a falta de otra palabra, podría 1lamarse un realismo mágico» ${ }^{1}$. Este procedimiento lo aplica también a la realidad histórica con el fin de obtener un conocimiento mejor del hombre total y de su relación con las circunstancias que lo rodean. De aquí se desprende que trate de desentrañar del rico venero de la conseja popular esas leyendas que representan la transformación mítica que sufren los hechos y personajes históricos en la mente del pueblo, y que forman una parte fundamental de la cultura venezolana.

Para Uslar Pietri, la mayor fuente del material mágico-realista se encuentra en la conseja popular, que para él representa «ese tesoro poético y moral, que las ayas venidas de las aldeas transmitían a los niños soñolientos y maravillados» ${ }^{2}$. Vale la pena recordar la narración que el aya de Fernando e Inés Fonta, en Las lanzas coloradas (1931), les hace en un caluroso mediodía, sentados a la sombra de un árbol, acerca del nacimiento del Niño Jesús y la matanza de los Santos Inocentes ${ }^{3}$. En su ensayo

\footnotetext{
${ }^{1}$ Arturo Uslar Pietri, Letras y hombres de Venezuela (Madrid: Editorial Mediterráneo, 1974), p. 287.

${ }^{2}$ Ibid., p. 246.

${ }^{3}$ En Las lanzas coloradas, Uslar incluye un cuento que el aya de Fernando e Inés Fonta les contara cuando niños: «Cuando nació Papá Dios estaba chiquitico, chiquitico, como una parapara. San José carpinteaba y la Virgen rezaba el rosario. Pero ellos vivían en la hacienda de un hombre maluco que les echaba muchas
} 
«Tío Tigre y Juan Bobo», Uslar critica la falta de utilización de este invaluable tesoro de tradición popular en la literatura venezolana. Dice:

Poco nos hemos preocupado de las formas en que el pueblo, espontáneamente, ha revelado sus sentimientos, sus pensamientos, sus complejos o, más simplemente, su propio aprendizaje y sabiduría. Lo que la vida y la tierra le han enseñado, o han permitido que sobreviva de lo que otros le enseñaron.

De todo ese conjunto, que es poesía, música, danza y relato, es el relato lo que me ha parecido más próximo y aprehensible. El que reduce a términos más simples el oculto mensaje del alma criolla ${ }^{4}$.

Invita a los escritores a ahondar en la profundidad y orígenes de las leyendas, consejas y personajes de la tradición oral, porque:

En los mitos y leyendas que nuestro pueblo conserva y transmite oralmente hay mucho más de lo que podríamos llamar la concepción venezolana del mundo, su espíritu, su vida, y su moral, que en todas las obras cultas que han pretendido explicarlo.

Sus ideas de la sociedad, de la justicia, del bien, del mal, de la felicidad, de lo bello, de lo sobrenatural, surgen diáfanas de esas sabrosas leyendas y consejas sobre el alma del Tirano Aguirre, el carretón de las ánimas, el cantor Florentino, Juan Bobo y los personajes de su comedia animal ${ }^{5}$.

Y reitera el autor que «en la conciencia del pueblo llega a establecerse un ancho canal de comunicación entre lo mítico y lo real» ${ }^{6}$. En Red

lavativas a los pobres negros y a todas las gentes. $Y$ va el Diablo y lo tienta. ;Ave, María Purísima! $Y$ el hombre maluco era el rey, y estaba vestido de oro, con un gorro colorado, y vivía en una casa grandota, y tenía buenas mulas, y daba unos banquetes con casabe y cochino y guarapo. Pero el rey quería matar a Papa Dios. antes que Papa Dios tuviera tiempo de montársele. Y va y le dice un día al mayordomo: "iMayordomo, venga acá! Usted va a salir ahorita mismo y me va a matar a todos los muchachos que haya. Ya lo sabe. Que no se salve ninguno." Y el mayordomo le dijo: "¡Ay, Misia Carramajestad, así se hará!" Y salió y empezaron a matar muchachos. Daban grima ese sangrero y esa gritería y ese pilón de muertos. iY mata y mata gente! iY mata y mata gente! iY mata y mata gente! Hasta que se cansaron. Pero a Papa Dios, iah, caramba!, se lo había avisado un ángel y se salvó en su burro. $Y$ entonces, el mayordomo fue a casa del rey y dijo: "Ay, Misia Carramajestad, ya los matamos a toditicos!'” Y entonces, el rey dio un fiestón, donde chorreaban los dulces y la mantequilla; pero a mí no me tocó ni tanto así..." (Las lanzas coloradas [Buenos Aires: Editorial Losada, S. A., 1949], pp. 27-28).

${ }^{4}$ Arturo Uslar Pietri, Letras y hombres, pp. 246-247.

${ }^{5}$ Ibid., p. 247.

${ }^{6}$ Ibid., p. 250. 
(1936), su segunda colección de cuentos, Uslar explora este mundo mágico que se encuentra presente en la conseja popular proveniente de la tradición oral. El crítico Domingo Miliani ${ }^{7}$ expresa su opinión sobre Red en los siguientes términos:

Realismo mágico en el mejor de los sentidos, es la tendencia que edifica esta segunda obra de cuentos publicada por Uslar Pietri. Libro que, si no puede considerarse renovador, puesto que la renovación fue marcada por Barrabás y otros relatos, sí debe tenerse como aportación precursora de una corriente, dentro de la narración hispanoamericana, que estuvo llamada a predominar en los últimos veinte años de su historia: el realismo mágico ${ }^{8}$.

Esta percepción de lo misterioso, de lo mágico en la realidad, aunada a la transformación mitológica de los hechos históricos, fue, sin duda alguna, lo que inspiró a Uslar Pietri a escribir su cuento «El fuego fatuo», incluido en Red, que luego ampliaría en su novela El camino de El Dorado (1948). Por esta misma razón, en el cuento del indio Matías, con que comienza Las lanzas coloradas, su más afamada novela, Uslar explora la proporción mitológica que ha alcanzado la figura de Simón Bolívar en la mente sencilla del pueblo, que le otorga cualidades sobrenaturales capaces de contrarrestar los poderes del diablo.

El cuento principia con una narración hecha por el esclavo Espíritu Santo a varios esclavos de la hacienda El Altar, propiedad de la familia Fonta. Espíritu Santo empieza su relato describiendo una noche tormentosa en la que el indio Matías y su gente avanzaban dificultosamente entre el lodazal y los relámpagos. Matías, que «tenía pacto con el diablo y por ese pacto nadie se la podía ganar [porque] Mandinga le sujetaba la lanza» ${ }^{9}$, dice el narrador que «no marchaba sino de noche, como murciélago cebado», y que «montaba en un potro que hedía a azufre y echaba candela» ${ }^{10}$, lo que hacía posible que la gente lo avistara desde una gran distancia. Como puede verse, Uslar introduce a este personaje rodeado de una atmósfera sobrenatural, que causa temor entre los oyentes de la narración y que, por otra parte, se hace perfectamente creíble entre

${ }^{7}$ En su obra Uslar Pietri, renovador del cuento venezolano, Miliani analiza la obra cuentística de Uslar y rinde un bien merecido tributo a sus cualidades como cultivador de este género narrativo.

${ }^{8}$ Domingo Miliani, Uslar Pietri, renovador del cuento venezolano (Caracas: Monte Avila Editores, C. A., 1969), pp. 123-124.

${ }^{9}$ Arturo Uslar Pietri, Las lanzas, p. 9.

${ }^{10}$ Ibid., p. 9. 
ellos debido a que la superstición es una de las bases sobre las que reposa la cultura venezolana.

En contraposición con el indio Matías, fiel representante del mal, aparece la figura recia y benefactora de El Libertador. Es un marcado contraste de luz y sombra que utiliza el autor con bastante frecuencia a lo largo de la novela. Matías aparece en medio de una «noche cerrada como pluma de zamuro», con un "cielo negro como fondo de pozo» ${ }^{11}$, mientras que Bolívar se hace visible por la luz de los relámpagos, y el aura de bondad que lo rodea le imprime una característica sobrenatural, cuyo poder lo capacita para inutilizar el maleficio del diablo:

-Aaagua y relámpagos. Iba la tropa apretada con el frío y el miedo y Matías adelante. Cuando ven venir un puño de gentes; jah, malhaya! Era poca la gente y venía con ellos un hombre chiquito y flaco, con patillas y unos ojos duros...

«Epa, amigo. ¿Usted quién es?» Y el chiquito le dice como sin querer: «¿Yo? Bolívar.» Persignársele al Diablo no fuera nada; echarle agua a la candela no fuera nada; pero decirle a Matías: « $¡$ Yo soy Bolívar!» Paró ese rabo y se fue como cotejo en mogote, ido de bola, con todo y pacto con Mandinga ${ }^{12}$.

También en el cuento «El fuego fatuo» Uslar utiliza el venero de la conseja popular proveniente de la tradición oral para crear un ambiente sobrenatural en el que el tardío conquistador Lope de Aguirre alcanza una estatura mitológica. Uslar explota la creencia, que todavía existe, de que «en todos los pueblos de Venezuela donde corre un fuego fatuo se dice que es el alma del Tirano Aguirre, y la gente devota se persigna como si les llegara el olor de azufre que anuncia el diablo» ${ }^{13}$. Según Domingo Miliani, en este cuento

puede llegarse casi a la definición del realismo mágico, ese hijo pródigo del surrealismo, tan citado por la crítica y tan poco estudiado en sus esencias. Es realismo mágico, porque de una realidad histórica, con enorme base épica, de un personaje rebelde que agigantó su estatura por el desafío al Rey de España, se produce la leyenda que deshace caballos, asesina multitudes sin escrúpulos, remata con la muerte de su propia hija y al final, siempre en labios del coro de viejas narradoras, es la superstición de una llama que surte del fogón y, por las noches,

${ }^{11}$ Ibid., p. 9.

12 Ibid., p. 10.

${ }^{13}$ Arturo Uslar Pietri, Valores humanos, II (Caracas-Madrid: Ediciones EDIME, 1968), p. 112. 
deambula sobre ciertas llanuras venezolanas en forma de fuego fatuo, luz en la cual la creencia popular ha perfilado al Tirano Aguirre ${ }^{14}$.

En el cuento aparecen dos viejas como únicos personajes, a los que Uslar identifica como la más vieja y la menos vieja. Estas señoras están cocinando en su rancho en una noche en que «humo y luz de cocina salen a hacer fantasmas» ${ }^{15}$. Las viejas han avistado el fuego fatuo y se ponen a invocar la protección divina diciendo: «-iAve María, guárdanos del Tirano Aguirre!» ${ }^{15}$ Luego comienzan a narrar episodios históricos que muestran la crueldad y el sadismo de Aguirre, imprimiéndoles, con sus comentarios, un carácter mítico:

-Matando gente seguía su camino a resbalones sobre las cabezas de los muertos...

-A resbalones también bajó los ríos en un barco pintado de sangre...

- Traía gente de todas partes que lo seguían con miedo, porque los puñales se le desviaban del cuerpo y los tiros se paraban en el aire para no tocarlo.

-Ahora la historia pasa en tierra. ¿Qué pasa?

- ¿Has visto pasar los entierros? Pasa él. ¿Has adivinado de noche en qué hora mueren los señalados? Pasa él ${ }^{17}$.

La tradición popular otorga a Aguirre cualidades sobrenaturales que le permiten matar individuos y diezmar poblaciones aun después de muerto; por esta razón, el fuego fatuo que las personas ven en las sabanas es para ellas como un espejo que reproduce imágenes míticas y esotéricas. Ante esta visión, sienten la necesidad de narrar escenas de la vida y, especialmente, de la muerte del Tirano. Una vez muerto en el relato, la vida de los que han experimentado el fenómeno sigue su curso normal:

La yoz de la más vieja pierde significación y se hace de la sustancia de la noche. El hurno empaña las luces y borra las paredes. Todo se sostiene sobre la agitación de las llamas.

La otra, queriendo ver en la humareda:

-No oigo. ¿Pasó la historia? ¿Ya ha muerto?

La fogata deja escapar hilos de llama que revolotean.

-iNo oigo!

${ }^{14}$ Miliani, pp. 119-120.

${ }^{15}$ Arturo Uslar Pietri, Catorce cuentos venezolanos (Madrid: Ediciones de la Revista de Occidente, 1969), p. 53.

${ }^{16}$ Ibíd., p. 53.

${ }^{17}$ Ibid., p. 55. 
Salta del fuego, como lámpara, como luz que navega sobre aceite, una llama quieta que recorre la noche.

-iAh!, se fue por el camino de la candela.

- Candela es, que viaja por la sombra cerrando los caminos.

E1 resplandor regresa, dando tumbos, desnudando los árboles.

Perdidas las figuras, las dos voces viven en la tiniebla.

- Ave María, guárdanos del alma del Tirano Aguirre, que pasa de noche en la candela ${ }^{18}$.

Como se ha visto en estos cuentos, Uslar Pietri utiliza las fuentes de la conseja popular para reflejar la reacción del individuo y de las masas ante los mitos colectivos. Esta preocupación por la repercusión de los hechos en los seres humanos, que es una constante en su obra, es la motivación fundamental que lo insta a escribir. Reitera su posición al respecto cuando dice: «Es como una necesidad, que no da sosiego, de devolver lo que se ha recibido, un sentido religioso del valor y la función de las palabras, y la voluntad de reflejar, completar o definir lo que nos viene de la circunstancia, propuesto como enigma» ${ }^{19}$. En consecuencia, desentraña de la realidad estos enigmas y los expresa haciendo gala de su habilidad como mágico-realista.

${ }_{18}^{18}$ Ibid., pp. 60-61.

19 Arturo Uslar Pietri, Obras selectas (Madrid-Caracas: Ediciones EDIME, 1967), p. xi. 